\title{
Effects of Aggregation of Nuclear-transferred Mouse Embryos Developed from Enucleated Eggs Receiving ES Cells on In Vitro and In Vivo Development
}

\author{
Akiko YABUUCHI ${ }^{1)}$, Yoko KATO ${ }^{1)}$ and Yukio TSUNODA ${ }^{1)}$ \\ 1) Laboratory of Animal Reproduction, College of Agriculture, Kinki University, 3327-204 \\ Nakamachi, Nara 631-8505, Japan
}

\begin{abstract}
Nuclear-transferred mouse eggs receiving embryonic stem cells develop into blastocysts at a high rate, but their potential to develop into fetuses is very low. Therefore, the present study examined the effects of aggregating of two nuclear-transferred eggs at the 8-cell stage to increase the cell number of nuclear-transferred embryos. The proportion of implantation sites on gestational day 10.5 after transfer of aggregated nuclear-transferred embryos (53\%) was significantly higher than after single nuclear transfer $(29 \%)$ or serial nuclear-transfer $(37 \%)$. The proportion of implantation sites with fetuses did not differ significantly among the three groups (7 to 17\%). These results demonstrate that the low potential of nuclear-transferred embryos with embryonic stem cells to develop into fetuses is not due to the lower cell number of nuclear-transferred embryos.
\end{abstract}

Key words: ES cells, Nuclear transfer, Serial nuclear transfer, Aggregation

(J. Reprod. Dev. 48: 393-397, 2002)

C loned mice were recently produced after nuclear transfer of embryonic stem (ES) cells [1-7]. The potential of nuclear-transferred eggs receiving ES cells to develop into blastocysts in vitro is relatively high (11 to $86 \%$ ), but the proportions of live young that are born after transfer to recipients are low, and there are large variations depending on the nuclear transfer procedure used and the genetic background of the ES cells (1 to $21 \%)$. Serial nuclear transfer of ES cells by membrane fusion into unfertilized eggs and again into fertilized 2-cell embryos increased the probability of developing into blastocysts [3].

Due to the abnormal expression of imprinted genes [6], the placentae of cloned mice are two to three times heavier than those of controls, a large proportion of young die soon after birth due to respiration problems [1-4]. The rate of postnatal

Accepted for publication: March 22, 2002

Correspondence: $Y$. Tsunoda death is low if ES cells with a hybrid genetic background are used as nuclear donors, although the reason for this is not clear [2,5]. The developmental potential of nuclear-transferred eggs receiving ES cells with a hybrid genetic background, however, is higher than those with an inbred background [5]. The preimplantation embryos from an inbred mouse strain are generally more sensitive than those from F1 strain mice, as demonstrated by the "in vitro 2-cell block"phenomenon [8]. The low potential of cultured embryos with an inbred background to develop into young might be due to the lower cell number of the embryos compared with $F_{1}$ embryos [9]. Zhou et al. (2001) reported that the cell number of blastocysts that developed from nucleartransferred eggs with ES cells was lower than that of blastocysts fertilized in vivo. In the present study, we aggregated two nuclear-transferred embryos to increase the cell number and compared 
this procedure with single and serial nuclear transfer with regard to their potential to develop into fetuses.

\section{Materials and Methods}

\section{Donor embryonic stem cells}

The ES cell line, established from a male blastocyst of ROSA 26 transgenic mice [10] with a nonalbino inbred 129/sv background, was used at passages 18 to 26 .

\section{Nuclear transfer}

Chromosomes at the second metaphase of unfertilized eggs recovered from superovulated $\mathrm{F}_{1}$ $(\mathrm{C} 57 \mathrm{BL} / 6 \times \mathrm{C} 3 \mathrm{H})$ females were mechanically removed, and the eggs were used as the recipient eggs $[11,12]$. A single metaphase ES cell synchronized with nocodazole treatment [3] was fused with an egg from which the maternal chromosomes had been removed using inactivated Sendai virus (HVJ). Fused eggs were cultured for 1 $\mathrm{h}$ in M16 medium [13] supplemented with cytochalasin B and then cultured in $\mathrm{Ca}^{2+}$-free M16 medium containing $10 \mathrm{mM} \mathrm{Sr}^{2+}$ for $5 \mathrm{~h}$. Nucleartransferred eggs with one pronucleus and a second polar body were cultured for 1 or 4 days to the 2cell or blastocyst stage in M16 medium.

\section{Serial nuclear transfer and aggregation of embryos}

Serial nuclear transfer at the 2-cell stage was performed in some of the experiments according to previous reports $[11,12]$. Briefly, when the nucleartransferred eggs developed to the 2-cell stage, the nuclei of the embryos were fused with enucleated blastomeres of fertilized 2-cell embryos using inactivated Sendai virus (HVJ). Reconstituted embryos were cultured in vitro for 3 days. When nuclear-transferred eggs developed to the 8-cell stage, the zona pellucidae of the embryos were removed by treatment with $0.5 \%$ pronase, and two embryos were aggregated and cultured for 2 days.

\section{Cell number of blastocysts and embryo transfer}

The number of inner cell mass (ICM) cells and trophectoderm (TE) cells of the blastocysts that developed after single nuclear transfer, serial nuclear transfer, and aggregation were individually counted using double staining methods [14]. Briefly, zona pellucida-free blastocysts were incubated in M2 medium [15] supplemented with $10 \%$ rabbit anti-mouse serum for $30 \mathrm{~min}$, and then incubated in M2 with guinea pig serum at a 1:5 dilution, propidium iodide (10 $\mu \mathrm{g} / \mathrm{ml})$, and Hoechst $33342(10 \mu \mathrm{g} / \mathrm{ml})$ for $30 \mathrm{~min}$. Treated embryos were examined under a fluorescent microscope to count the number of ICM cells (stained light blue) and TE cells (stained pink).

Nuclear-transferred eggs that developed into blastocysts were transferred to the oviducts of day 1 , or uteri of day 2.5, pseudopregnant ICR strain albino females. Recipients were sacrificed on day 10.5 to examine the potential of the implants to develop into fetuses. Embryos were stained with $X$-gal staining to confirm their origin according to the procedures reported previously [16].

\section{Statistical analysis}

Data were analyzed using $\chi^{2}$ analysis (Tables 1 and 3 ) and Student's $t$-test (Table 2). A P value of less than 0.05 was considered to be statistically significant.

\section{Results}

Table 1 shows the in vitro development of nuclear-transferred eggs that received ES cells synchronized at the $\mathrm{M}$ phase. The proportion of fused eggs with ES cells was $82 \%$, and most of the eggs formed one pronucleus and a second polar body after parthenogenetic activation (90\%). Most of them $(97 \%)$ cleaved into the 2-cell stage and were then divided into three groups. In the single nuclear transfer group, embryos were cultured for another 3 days and $59 \%$ of them developed into blastocysts. In the serial nuclear transfer group, karyoplasts from 350 nuclear-transferred 2-cell embryos were fused with enucleated blastomeres of fertilized 2-cell embryos. In 337 embryos (97\%), 2 karyoplasts successfully fused with 2 blastomeres, but in 11 embryos $(3 \%)$, a single karyoplast fused with one blastomere. Because the potential to develop into blastocysts was not significantly different between these two types of fusion $(64 \%$ and $56 \%)$, the data were combined and summarized in Table 1 (63\%). For the last group, 257 aggregates were successfully produced from 516 zona pellucida-free 8 -cell embryos and $60 \%$ of them developed into blastocysts. The remaining aggregates stopped development at the morula 
Table 1. In vitro development of nuclear-transferred eggs receiving ES cells

\begin{tabular}{|c|c|c|c|c|c|c|}
\hline \multirow{2}{*}{$\begin{array}{l}\text { No. of } \\
\text { eggs fused } \\
\text { /used (\%) }\end{array}$} & \multirow{2}{*}{$\begin{array}{l}\text { No. of eggs } \\
\text { with one nucleus } \\
\text { and polar } \\
\text { body }(\%)\end{array}$} & \multirow{2}{*}{$\begin{array}{l}\text { No. of eggs } \\
\text { developed to } \\
\text { 2-cell (\%) }\end{array}$} & \multirow{2}{*}{$\begin{array}{l}\text { Type of } \\
\text { nuclear- } \\
\text { transfer }\end{array}$} & \multirow{2}{*}{$\begin{array}{l}\text { No. of eggs } \\
\text { cultured }\end{array}$} & \multicolumn{2}{|c|}{ No. of eggs develop to (\%) } \\
\hline & & & & & morula & blastocyst \\
\hline \multirow[t]{3}{*}{$1383 / 1686(82)$} & $1245(90)$ & $1208(97)$ & single & 211 & $163(77)$ & $125(59)$ \\
\hline & & & serial & 350 & $279(80)$ & $222(63)$ \\
\hline & & & aggregation & 257 & - & $154(60)$ \\
\hline
\end{tabular}

Table 2. Cell numbers of blastocysts developed from nuclear-transferred

\begin{tabular}{|c|c|c|c|}
\hline \multirow{2}{*}{$\begin{array}{l}\text { Type of } \\
\text { nuclear- } \\
\text { transfer }\end{array}$} & \multicolumn{3}{|c|}{ Cell numbers \pm SD (No. of blastocysts) } \\
\hline & inner cell mass & trophectoderm & total \\
\hline Single & $8.3 \pm 2.0^{\mathrm{a}}$ & $29.1 \pm 5.8^{\mathrm{a}}$ & $37.4 \pm 6.7^{\mathrm{a}}(\mathrm{n}=10)$ \\
\hline Serial & $12.9 \pm 2.7^{b}$ & $32.0 \pm 5.4^{\mathrm{a}}$ & $44.9 \pm 7.6^{b}(\mathrm{n}=8)$ \\
\hline Aggregation & $15.7 \pm 5.2^{b}$ & $38.0 \pm 3.6^{b}$ & $53.7 \pm 7.3^{c}(n=6)$ \\
\hline
\end{tabular}

Values with different superscripts within the same column are significantly different $(\mathrm{P}<0.05)$.

Table 3. In vivo development of nuclear-transferred eggs receiving ES cells

\begin{tabular}{lcccc}
\hline $\begin{array}{l}\text { Type of } \\
\text { nuclear- } \\
\text { transfer }\end{array}$ & $\begin{array}{c}\text { No. of } \\
\text { embryos } \\
\text { transferred }\end{array}$ & $\begin{array}{c}\text { No. of } \\
\text { embryos } \\
\text { implanted }(\%)\end{array}$ & $\begin{array}{c}\text { No. of } \\
\text { fetuses } \\
(\%)\end{array}$ & $\begin{array}{c}\text { No. of } \\
\text { fetuses with } \\
\text { beating heart (\%) }\end{array}$ \\
\hline $\begin{array}{l}\text { Single } \\
\text { Serial }\end{array}$ & 62 & $18(29)^{\mathrm{a}}$ & $7(11)$ & $4(6)$ \\
Aggregation & 71 & $26(37)^{\mathrm{a}}$ & $5(7)$ & $3(4)$ \\
\hline
\end{tabular}

$\mathrm{a}$ and $\mathrm{b}$ are significantly different $(\mathrm{P}<0.05)$.

stage. The potential of nuclear-transferred eggs to develop into blastocysts was not significantly different among the three groups.

As shown in Table 2, the ICM and TE number and the total cell numbers of blastocysts in the single nuclear transfer group were significantly lower than those of blastocysts in the aggregation group. The ICM cell number and total cell numbers of blastocysts in the serial nuclear transfer group were significantly higher than those in the single nuclear transfer group, but the TE cell number and total cell number in the serial nuclear transfer group were lower than those in the aggregation group.

The implantation rate of blastocysts on day 10.5 was significantly higher in the aggregation group than in the other two groups (Table 3 ). The proportion of implantation sites with fetuses, however, was not significantly different between the groups. The proportion of fetuses with a beating heart and the average number of somites $(23.6,23.6$, and 23.5 respectively) were not significantly different among groups. All fetuses were positive for $\mathrm{X}$-gal staining.

\section{Discussion}

The hypothesis of the present study was that aggregation of two nuclear- transferred embryos would increase the potential to develop into fetuses/offspring, because blastocysts that develop from nuclear-transferred eggs with ES cells have lower cell numbers [7]. The present study demonstrated that the implantation rate of aggregated embryos on day 10.5 was significantly higher than that of embryos after single or serial nuclear transfer. The proportion of implantation 
sites with fetuses, however, was not different among groups, and more than half of the fetuses did not have a beating heart. This is the first report to demonstrate that the low potential of nucleartransferred eggs with ES cells to develop into fetuses/offspring is not due to the low cell numbers of the nuclear-transferred embryos. The proportion of fetuses after transfer of nuclear-transferred eggs with ES cells gradually decreased soon after implantation: $48 \%$ on day $6.5,20 \%$ on day 8.5 (Amano, Kato, and Tsunoda, unpublished findings), and $11 \%$ on day 10.5 (present study). Although the nuclear-transferred eggs with ES cells developed normally into blastocysts at a high rate, the blastocysts did not develop into fetuses at a high rate. The inferior potential of both ICM cells and TE cells of nuclear-transferred blastocysts underlies the low developmental rate of nucleartransferred eggs, because both tetraploid blastocysts injected with ICM cells of nucleartransferred blastocysts and nuclear-transferred tetraploid blastocysts injected with ICM of diploid blastocysts have low developmental potential [17].

Humpherys et al. (2001) reported that imprinted gene expression, such as H19, Igf2, Peg1, Meg1, and Gapdh, in ES cells is extremely unstable during maintenance in culture and there are also variations of imprinted gene expression in healthy cloned mice, as in the case of the methylation pattern in somatic-cell cloned mice [18]. The low potential of nuclear-transferred eggs to develop into fetuses and into young might be due not only to a single gene modification but also to a cumulative effect of the modification of multiple genes. The extent and type of abnormal gene expression might determine the timing of the retardation of embryos during pregnancy. This might be why aggregated nuclear- transferred embryos with a high ability to implant in the present study did not develop to fetuses at a high rate; gene modification was doubled due to the aggregation. Thus, if a primary culture of somatic cells were used as nuclear donors, the results might be different. The present study did not confirm the previous findings of Amano et al. (2001a), in which serial nuclear transfer of ES cells increased the potential to develop into blastocysts. This discrepancy might be due to differences in the ES cell lines used for nuclear transfer, the F2 genetic background in the previous report, and the inbred genetic background in the present study.

In contrast to ES cells with an inbred genetic background, the potential of nuclear-transferred eggs receiving ES cells with a hybrid genetic background to develop into fetuses/offspring was relatively high and the postnatal death rate was low, when a direct injection method in which a small volume of cytoplasm was incorporated into the recipient eggs [5] was used. To increase the viability of nuclear-transferred eggs, further methodological research into the effects of different ES-cell-lines will be required.

\section{Acknowledgement}

The authors would like to thank Drs. A. Surani and T. Tada for providing the NR2 embryonic stem cell lines. This work was supported by grants from the Ministry of Education, Science, and Culture (12358014, 13308054, 14034259), the Research Grant (13B-1) for Nervous and Mental Disorders from the Ministry of Health and Welfare, and the Program for Promotion of Basic Research Activities for Innovative Biosciences (PROBRAIN).

\section{References}

1. Wakayama T, Rodriguez I, Perry AC, Yanagimachi R, Mombaerts P. Mice cloned from embryonic stem cells. Proc Natl Acad Sci USA 1999; 96: 14984-14989.

2. Rideout WM III, Wakayama T, Wutz A, Eggan K, Jackson-Grusby L, Dausman J, Yanagimachi R, Jaenisch R. Generation of mice from wild-type and targeted ES cells by nuclear cloning. Nature Genet 2000; 24: 109-110.

3. Amano T, Tani T, Kato Y, Tsunoda Y. Mouse cloned from embryonic stem (ES) cells synchronized in metaphase with nocodazole. J Exp Zool 2001a; 289:
139-145.

4. Amano T, Kato $\mathbf{Y}$, Tsunoda $\mathbf{Y}$. The full term development of enucleated mouse oocytes fused with ES cells from different cell lines. Reproduction 2001b; 121: 729-733.

5. Eggan K, Akutsu H, Loring J, Jackson-Grusby L, Klemm M, Rideout WM III, Yanagimachi R, Jaenisch R. Hybrid vigor, fetal overgrowth, and viability of mice derived by nuclear cloning and tetraploid embryo complementation. Proc Natl Acad Sci USA 2001; 98: 6209-6214. 
6. Humpherys D, Eggan $K$, Akutsu H, Hochedlinger K, Rideout WM III, Biniszkiewicz D, Yanagimachi $\mathbf{R}$, Jaenisch R. Epigenetic instability in ES cells and cloned mice. Science 2001; 293: 95-97.

7 Zhou Q, Jouneau A, Brochard V, Adenot P, Renard JP. Developmental potential of mouse embryos reconstructed from metaphase embryonic stem cell nuclei. Biol Reprod 2001; 65: 412-419.

8. Whitten WK, Biggers JD. Complete development in vitro of the pre-implantation stages of the mouse in a simple chemically defined medium. J Reprod Fertil 1968; 17: 399-401.

9. Nakamura K, Tsunoda Y. Chimaeras obtained by nuclear transplantation technique in the mouse. Jpn J Anim Reprod 1987; 33: 82-87.

10. Friedrich G, Soriano P. Promoter traps in embryonic stem cells: A genetic screen to identify and mutate developmental genes in mice. Genes Dev 1991; 5: 1513-1523.

11. Tsunoda Y, Kato Y. Full-term development after transfer of nuclei from 4-cell and compacted morula stage embryos to enucleated oocytes in the mouse. $J$ Exp Zool 1997; 278: 250-254.

12. Yabuuchi A, Tani T, Kato Y, Tsunoda Y. Nuclear transfer of mouse follicular epithelial cells pretreated with spermine, protamine, or putrescine. J Exp Zool 2001; 289: 208-212.

13. Whittingham DG. Culture of mouse ova. J Reprod Fertil 1971; 14 (suppl): 7-21.

14. Papaioannou VE, Ebert KM. The preimplantation pig embryo: Cell number and allocation to trophectoderm and inner cell mass of the blastocyst in vivo and in vitro. Development 1988; 102: 793-803.

15. Fulton BP, Whittingham DG. Activation of mammalian oocytes by intracellular injection of calcium. Nature 1978; 273: 149-151.

16. Kato Y, Rideout WM III, Hilton K, Barton SC, Tsunoda Y, Surani MA. Developmental potential of mouse primordial germ cells. Development 1999; 126: 1823-1832.

17. Amano T, Kato Y, Tsunoda Y. The developmental potential of the inner cell mass of blastocysts derived from mouse ES cells. Cell Tissue Res 2002; 307: 367-370.

18. Ohgane J, Wakayama T, Kogo Y, Senda S, Hattori $\mathbf{N}$, Tanaka S, Yanagimachi $\mathbf{R}$, Shiota K. DNA methylation variation in cloned mice. Genesis 2001; 30: 45-50. 